\title{
EFEKTIVITAS EKSTRAK BUAH DELIMA (Punica granatum) TERHADAP PENINGKATAN KADAR KALSIUM DALAM DARAH TIKUS PUTIH (Rattus norvegicus)
}

\author{
Indy Variety ${ }^{*}$, Edrizal $^{* *}$, Eka Desnita ${ }^{* * *}$ \\ "Mahasiswa, FKG Universitas Baiturrahmah padang \\ *** Bagian Ortodonti, FKG Universitas Baiturrahmah Padang \\ ${ }^{* * *}$ Bagian Farmasi, FKG Universitas Baiturrahmah Padang
}

\begin{tabular}{lr} 
KATA KUNCI \\
\hline $\begin{array}{l}\text { Extract of } \\
\text { granatum, } \\
\text { Dose }\end{array}$ & $\begin{array}{r}\text { Punica } \\
\text { Calcium, }\end{array}$
\end{tabular}

Ekstrak Punica granatum, Kalsium, Dosis

\begin{abstract}
ABSTRAK
Pomegranate (Punica granatum) has been known to contain many active mineral ingredient such as iron, magnesium, potassium, zinc, phosphorus, including calcium. Calcium levels in this fruit are $10 \mathrm{mg}$ in every $100 \mathrm{~g}$ it is almost equivalent to the levels of vitamin $C$ in this fruit. The research aims to know the benefit and effectiveness of the extract pomegranate (Punica granatum) to increase calcium blood level of the white rats (Rattus norvegicus). This study used an experimental laboratory method. The pomegranate extract (Punica granatum) made in the Kopertis Laboratory X. Dose of pomegranate (Punica granatum) made in pharmaceutical laboratory Andalas University, Padang are $2 \mathrm{mg}, 4 \mathrm{mg}, 8 \mathrm{mg}, 16 \mathrm{mg}$ and negative control without giving any extract. The results of this study showed that the higher the dose given, also increase the calcium blood level. Compared with the negative control group, the pomegranate extract (Punica granatum) at doses of $2 \mathrm{mg}, 4 \mathrm{mg}, 8 \mathrm{mg}$ resulted in calcium blood levels are lower than the negative control. While on the 16mg dose showed elevated the calcium blood levels compared to the negative control group. This shows that the smallest dose of pomegranate extract that is able to increase the calcium blood levels at 16mg dose. Anova test showed a significant result of the observation value $(p<0.05)$ in increase a calcium blood levels of white rats (Rattus Norvegicus). Conclusion pomegranate extract (Punica Granatum) has an effect in increasing the calcium blood level but not significant.
\end{abstract}

Buah Delima (Punica granatum) telah terbukti banyak mengandung bahan mineral aktif yaitu iron, magnesium, potassium, zinc, phosphorus, termasuk calcium. Kadar kalsium yang terdapat pada buah ini sebesar 10mg dalam 100g hampir setara dengan kadar vitamin $\mathrm{C}$ yang terdapat didalamnya. Telah dilakukan penelitian yang bertujuan untuk mengetahui manfaat dan efektifitas ekstrak buah delima merah (Punica granatum) terhadap peningkatan kadar kalsium dalam darah tikus putih (Rattus norvegicus). Metode penelitian yang digunakan adalah Eksperimental Laboratorium. Pembuatan ekstrak buah delima (Punica granatum) dilakukan di Laboratorium Kopertis Wilayah X Padang, Sumatera Barat. Pemberian ekstrak buah delima (Punica granatum) $2 \mathrm{mg}, 4 \mathrm{mg}, 8 \mathrm{mg}, 16 \mathrm{mg}$ dan kontrol negatif tanpa pemberian sediaan apapun dilakukan di Laboratorium Farmasi Universitas Andalas, Padang. Hasil penelitian menunjukan bahwa semakin tinggi dosis yang diberikan, semakin meningkat pula kadar kalsium yang terdapat didalam darah tersebut. Namun jika dibandingkan dengan kelompok kontrol negatif, pemberian ekstrak buah delima (Punica Granatum) pada dosis pemberian $2 \mathrm{mg}, 4 \mathrm{mg}, 8$ mg menghasilkan kadar kasium dalam darah yang lebih rendah jika 
dibandingkan kontrol negatif. Sedangkan pada pemberian dosis $16 \mathrm{mg}$ menunjukan peningkatan kadar kalsium dalam darah dibandingkan dengan kelompok kontrol negatif. Hal ini menunjukan bahwa dosis terkecil ekstrak buah delima yang mampu untuk meningkatkan kadar kalsium dalam darah terdapat didalam pemberian ekstrak dengan dosis sebesar 16mg. Setelah dilakukan uji Anova yang hasilnya tampak terdapat pengaruh langsung hari terhadap skor observasi $(\mathrm{p}<0,05)$ dalam peningkatan kadar kalsium dalam darah tikus putih. Kesimpulan dari penelitian ini maka dapat dikatakan bahwa ekstrak buah delima (Punica Granatum) mempunyai efek dalam peningkatan kadar kalsium dalam darah tikus putih (Rattus Norvegicus) namun tidak signifikan.

\section{PENDAHULUAN}

Kalsium adalah mineral yang paling berlimpah dalam tubuh manusia, dan regulasi yang ketat yang diperlukan untuk banyak fungsi biologis kritis, seperti mineralisasi tulang dan gigi, kontraksi otot, konduksi saraf, pelepasan hormon, dan pembekuan darah. ${ }^{1}$ Oleh karena itu, mengkonsumsi cukup kalsium setiap hari untuk mengembalikan kalsium yang hilang sangat dianjurkan. Jika kebutuhan kalsium dalam darah tidak bisa dipenuhi, tubuh akan mengambil kalsium dari tulang yang berfungsi sebagai gudang penyimpanan utama kalsium untuk mempertahankan kecukupan kalsium dalam darah. ${ }^{2}$

Penggunaan obat tradisional cenderung meningkat dikarenakan adanya isu back to nature dan kepercayaan masyarakat terhadap kelebihan obat tradisional dibandingkan dengan obat modern. ${ }^{3}$ Sumber kalsium selain terdapat pada susu, juga terdapat pada sayuran, kacang-kacangan, serta buahbuahan, salah satunya buah delima (Punica Granatum). ${ }^{4}$ Menurut penelitian USDA National Nutrient dalam The National
Agricultural Library pada tahun 2014, didalam buah delima banyak terkandung bahan mineral aktif yaitu iron, magnesium, potassium, zinc, phosphorus, termasuk calcium. Kadar kalsium yang terdapat pada buah ini sebesar $10 \mathrm{mg}$ dalam $100 \mathrm{~g} .{ }^{5}$ Terdapat tiga jenis buah delima (Punica granatum) yang dikelompokkan berdasarkan warna buahnya, yakni buah delima putih, delima merah, dan delima hitam. Dari ketiga jenis buah delima itu yang paling terkenal adalah delima merah. Delima merah memiliki rasa lebih manis dan lebih segar, daging buahnya berair dan merupakan salah satu dari jenis delima yang sering dijadikan sebagai tanaman hias. ${ }^{6,7}$ Peningkatan kebutuhan kalsium terjadi pada masa pertumbuhan, kehamilan, menyusui, defisiensi kalsium dan tingkat aktifitas fisik yang meningkatkan densitas tulang. ${ }^{4}$ Kalsium berperan sangat penting dalam pembentukan dan stabilitas tulang alveolar, sehingga fungsi dan manfaat tulang alveolar dapat optimal. Perempuan beresiko lebih besar dalam kehilangan gigi, hal ini disebabkan hilangnya massa tulang skeletal 
dan tinggi crestal alveolar lebih cepat terjadi setelah menopause, ini merupakan salah satu penyebab utama kehilangan gigi umum. ${ }^{9}$ Pada ibu hamil serta pada masa pertumbuhan dan kalsifikasi gigi (bayi dan anak-anak), pemasukan kalsium yang adekuat perlu diperhatikan karena pada masa inilah yang dapat mempengaruhi komposisi mineral dan struktur jaringan keras gigi. ${ }^{10}$ Sehingga dapat disimpulkan bahwa kebutuhan kalsium pada wanita lebih besar dibandingkan dengan laki-laki. Diharapkan dengan adanya pemberian asupan mineral melalui makanan dapat meningkatkan kadar kalsium dalam darah. Kebutuhan kalsium berbeda pada setiap jenis kelamin dan umur, rata-rata kebutuhan asupan kalsium pada bayi lahir sampai satu tahun 360mg sampai 540mg, anak-anak usia satu tahun sampai sepuluh tahun $800 \mathrm{mg}$, remaja sebelas tahun sampai delapan belas tahun 1000mg, pria dan wanita dewasa $800 \mathrm{mg}$, wanita hamil dan menyusui $1200 \mathrm{mg} .{ }^{4}$

Berdasarkan penjelasan diatas penulis berminat melakukan sebuah penelitian dimana peneliti bertujuan ingin mengetahui efektifitas ekstrak buah delima (Punica granatum) terhadap peningkatan kadar kalsium dalam darah tikus (Rattus norvegicus). Hasil penelitian ini diharapkan dapat memberikan informasi kepada masyarakat bahwa kalsium yang terdapat pada delima merah (Punica granatum) mempunyai pengaruh terhadap kadar kalsium dalam darah sehingga dapat menjadi acuan dasar bagi peneliti selanjutnya. Menambah wawasan dan pengetahuan serta diharapkan dapat menjadi salah satu anternatif memenuhi asupan kalsium dalam tubuh, disamping kelebihannya yang merupakan bahan alami.

\section{BAHAN DAN METODE}

Bahan yang digunakan adalah masker, handscoon, kertas saring, kapas, ekstrak buah delima, etanol $96 \%$, eter inhalasi, makanan dan minuman tikus, tabung eppendorf, aquadest. Penelitian ini merupakan ekperimental laboratorium dengan rancangan control group post test only design. Subyek penelitian adalah 20 ekor tikus betina (Rattus norvegicus) dengan jenis galur wistar berumur 8-12 minggu dengan berat kira-kira 200-300 gram dimana dibagi menjadi 5 kelompok.

Buah delima yang telah dibersihkan dan dikupas kulitnya, dikering-angin selama $2 \times 24$ jam, dirajang dan ditimbang sebanyak yang dibutuhkan dan setelah itu delima dihacurkan dengan blender kemudian ditimbang. Ektraksi sampel dilakukan dengan metoda maserasi dengan etanol 96\% selama 3 hari dengan satu kali penyaringan. Maserat diaduk setiap harinya dan setelah hari ke-3 lakukan penyaringan. Semua maserat diuapkan dengan rotary evaporator sampai diperoleh ekstrak kental. ${ }^{11}$

Penelitian ini menggunakan hewan coba berupa tikus putih (Rattus norvegicus) betina strain Wistar berumur 8-12 minggu. Berat 
badan tikus berkisar 200-300 gram. Hewan coba dipelihara dan dikelompokan dalam 5 kandang plastik bertutup, tiap kandang ditempatkan 4 ekor tikus betina. Hewan coba diaklimatisasi dengan pemberian makanan berupa ransum basal dan minum air suling secara ad libitum pada semua tikus. ${ }^{12}$ Ekstrak buah delima yang di ujikan kepada tikus yaitu $2 \mathrm{mg}$, 4mg, $8 \mathrm{mg}$, 16mg, serta kontrol negatif (tanpa pemberian sedian apapun). Pemberian dosis berdasarkan tabel konversi dosis dari manusia ke tikus menurut Laurance (1984). Untuk pemberian sampel ke tikus dibuat dalam bentuk volume dari masing- masing dosis sehingga volume pemberian ekstrak untuk tikus berturut-turut dari kelompok perlakuan 1 sampai perlakuan 4 menjadi $0,2 \mathrm{cc}, 0,4 \mathrm{cc}, 0,8 \mathrm{cc}$, dan 1,6cc. Timbang sedian ekstrak kental buah delima sebanyak 100 gram pada timbangan analitik, lalu diencerkan dengan aquadest sebanyak 10cc dengan cara digerus di dalam lumpang hingga mendapatkan masa yang homogen. Selanjutnya sediaan tersebut diambil menggunakan disposable syringe sebanyak $0,2 \mathrm{cc}$ untuk pemberian dosis $2 \mathrm{mg} / 200 \mathrm{gr}$ tikus, 0,4cc untuk pemberian dosis 4mg/200gr tikus, 0,8cc untuk pemberian dosis 8mg/200gr tikus, dan 1,6 cc untuk pemberian dosis $16 \mathrm{mg} / 200 \mathrm{gr}$ tikus. Hewan percobaan dikelompokkan menjadi 5 kelompok yang masing- masing kelompok terdiri dari 4 ekor tikus. Kelompok 1 : kontrol negatif, tanpa diberikan sedian apapun, kelompok 2 : diberikan ekstrak buah delima dosis $2 \mathrm{mg}$, kelompok 3 : diberikan ekstrak buah delima dosis 4mg, kelompok 4 : diberikan ekstrak buah delima dosis 8mg, kelompok 5 : diberikan ekstrak buah delima dosis16mg. Sedian uji diberikan pada hewan percobaan sebanyak 2 kali sehari pagi dan sore hari secara oral menggunakan jarum gavage sesuai dosis yang ditentukan selama empat belas hari.

Pengambilan sampel darah dilakukan pada hari kelima belas dari perlakuan. Hewan percobaan atau tikus terlebih dahulu dibius inhalasi dengan menggunakan larutan eter. Setelah tikus dalam keadaan tidak sadar, dilakukan dislokasi pada leher. Darah langsung diambil pada daerah leher sebanyak $5 \mathrm{ml}$. Sampel darah tikus yang diambil dimasukkan ke dalam tabung reaksi dan ditunggu selama 20 menit agar membeku sempurna dan keluar serumnya. Kemudian disentrifugasi (Hettich Zentrifugen) dengan kecepatan 3000 rpm selama 20 menit. $^{12}$ Pada penelitian ini serum yang telah terpisah dengan plasma diambil menggunakan spuit, masing-masing sampel didapatkan serum sebanyak $1,5 \mathrm{ml}$.

Pengukuran kadar kalsium dalam darah menggunakan alat spektofotometri sinar tampak (UV-Vis). Cara menganalisis kadar kalsium dalam darah mengikuti petunjuk dari DiaSys Diagnostic Systems (2009) adalah dengan menggunakan larutan standar kalsium yang dipipet dengan mikropipet

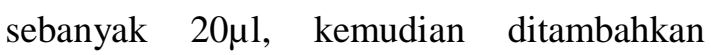


reagen kalsium ASFS 2ml lalu inkubasi dengan suhu $37^{\circ} \mathrm{C}$ selama 5 menit. Setelah itu, larutan diukur di dalam alat spectofotometer UV-Vis sehingga mendapatkan konsentrasi kadar kalsium standar. Setelah itu siapkan Aquadest $20 \mu \mathrm{m}$ dan ditambahkan reagen kalsium AS FS $2 \mathrm{ml}$ di tabung reaksi. Larutan divortex (dihomogenkan) kemudian diinkubasi selama 5 menit. Larutan aquadest dimasukan ke dalam spectrofotometer UV-Vis. Setelah itu, sampel serum dipipet sebanyak $20 \mu \mathrm{m}$ ke dalam tabung reaksi kemudian ditambahkan reagen Calsium ASFS 2ml. Larutan divortex (dihomogenkan), kemudian diinkubasi selama 5 menit dengan suhu 37 derajat celcius. Setelah itu dianalisis dengan alat Spectofotometer sinar tampak (UV-Vis) pada panjang gelombang $650 \mathrm{~nm}$. Cara pengukuran serum dari setiap sampel dilakukan sama dengan cara diatas dan dilakukan pembacaan satu persatu pada alat Spectofotometer sinar tampak (UV- Vis). Hasil pembacaan kemudian dibandingkan dengan kurva standar, sehingga diperoleh kadar kalsium dalam panjang gelombang nm lalu di hitung dan diubah menjadi satuan $\mathrm{mg} / \mathrm{dl}$ atau ppm. ${ }^{13}$

\section{HASIL DAN PEMBAHASAN}

Berdasarkan hasil pengamatan dan penelitian terhadap tikus kelompok kontrol negatif, hasil pengukuran dapat dilihat pada tabel.1.

Tabel 1.Pengamatan Kelompok Kontrol Negatif

\begin{tabular}{cccl}
\hline Hewan Uji & Serapan & $\begin{array}{c}\text { Konsentrasi } \\
\text { Kalsium } \\
\text { Plasma mg/dL }\end{array}$ & Keterangan \\
\hline Tikus I & 0,860 & 10,411 & Normal \\
\hline Tikus II & 0,968 & 11,719 & Normal \\
\hline Tikus III & 0,781 & 9,457 & Normal \\
\hline Tikus IV & 0,901 & 10,91 & Normal \\
\hline
\end{tabular}

Hasil pengukuran kadar kalsium dalam darah terhadap tikus kelompok perlakuan ekstrak buah delima $2 \mathrm{mg}$ dapat dilihat pada tabel.2.

Tabel 2. Pengamatan Kelompok Perlakuan Dosis 2mg

\begin{tabular}{cccc}
\hline Hewan Uji & Serapan & $\begin{array}{c}\text { Konsentrasi Kalsium } \\
\text { Plasma mg/dL }\end{array}$ & Keterangan \\
\hline Tikus I & 0,415 & 5,024 & Hipokalsemia \\
\hline Tikus II & 0,538 & 6,513 & Hipokalsemia \\
\hline Tikus III & 0,424 & 5,133 & Hipokalsemia \\
\hline Tikus IV & 0,379 & 4,588 & Hipokalsemia \\
\hline
\end{tabular}

Hasil pengukuran kadar kalsium dalam darah terhadap tikus kelompok perlakuan ekstrak buah delima $4 \mathrm{mg}$ dapat dilihat pada tabel.3. 
Variety : Efektivitas ekstrak buah delima (Punica Granatum)...

Tabel 3.Pengamatan Kelompok Perlakuan Dosis 4mg

\begin{tabular}{cccc}
\hline Hewan Uji & Serapan & $\begin{array}{c}\text { Konsentrasi Kalsium } \\
\text { Plasma mg/dL }\end{array}$ & Keterangan \\
\hline Tikus I & 0,471 & 5,702 & Hipokalsemia \\
\hline Tikus II & 0,581 & 7,033 & Hipokalsemia \\
\hline Tikus III & 0,412 & 4,987 & Hipokalsemia \\
\hline Tikus IV & 0,515 & 6,234 & Hipokalsemia \\
\hline
\end{tabular}

Hasil pengukuran kadar kalsium dalam darah terhadap tikus kelompok perlakuan ekstrak buah delima $8 \mathrm{mg}$ dapat dilihat pada tabel.4.

Tabel 4. Pengamatan Kelompok Perlakuan Dosis 8mg

\begin{tabular}{cccc}
\hline Hewan Uji & Serapan & $\begin{array}{c}\text { Konsentrasi Kalsium } \\
\text { Plasma mg/dL }\end{array}$ & Keterangan \\
\hline Tikus I & 0,710 & 8,595 & Hipokalsemia \\
\hline Tikus II & 0,778 & 9,418 & $\begin{array}{c}\text { Hipokalsemia } \\
\text { ringan }\end{array}$ \\
\hline Tikus III & 0,684 & 7,845 & Hipokalsemia \\
\hline Tikus IV & 0,767 &, 285 & $\begin{array}{c}\text { Hipokalsemia } \\
\text { ringan }\end{array}$ \\
\hline
\end{tabular}

Hasil pengukuran kadar kalsium dalam darah terhadap tikus kelompok perlakuan ekstrak buah delima 16mg dapat dilihat pada tabel.5.

Tabel 5. Pengamatan Kelompok Perlakuan Dosis 16mg

\begin{tabular}{cccc}
\hline Hewan Uji & Serapan & $\begin{array}{c}\text { Konsentrasi Kalsium } \\
\text { Plasma mg/dL }\end{array}$ & Keterangan \\
\hline Tikus I & 0,894 & 10,823 & Normal \\
\hline Tikus II & 0,909 & 11,004 & Normal \\
\hline Tikus III & 0,856 & 10,363 & Normal \\
\hline Tikus IV & 0,936 & 11,331 & Normal \\
\hline
\end{tabular}

Berdasarkan uji deskriptif terhadap data hasil penelitian dengan dilakukan perhitungan rata-rata kadar kalsium dalam darah seluruh perlakuan, yang dituangkan pada diagram.

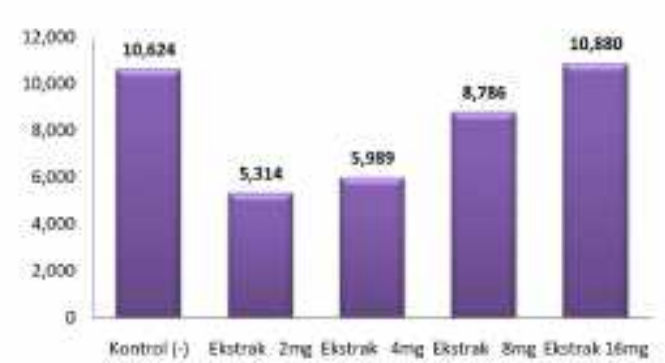

Diagram 1. Rata-rata Kadar Kalsium dalam Darah Seluruh Perlakuan
Berdasarkan diagram rata-rata kadar kalsium seluruh perlakuan didapatkan kesimpuan berupa, kadar rata-rata kalsium plasma kelompok kontrol adalah sebesar 10,62425 mg/dL, kadar kalsium dalam darah pada kelompok tikus kontrol ini dalam batasan normal. Sedangkan kadar rata-rata kalsium plasma kelompok perlakuan dengan pemberian dosis $2 \mathrm{mg}$ adalah 5,31450 
mg/dL, kadar kalsium dalam darah pada kelompok tikus ini mengalami penurunan dibandingkan kelompok kontrol negatife dan sudah berada ditahap hipokalsemia. Pada pemberian dosis $4 \mathrm{mg}$ kadar rata-rata kalsium plasma kelompok perlakuan adalah $5,98900 \mathrm{mg} / \mathrm{dL}$, kadar kalsium dalam darah pada kelompok tikus ini mengalami penurunan dibandingkan kelompok kontrol negatif dan sudah berada ditahap hipokalsemia. Namun kadar kalsium dalam kelompok pemberian dosis $4 \mathrm{mg}$ ini mengalami peningkatan kadar kalsium dibandingkan dengan kelompok pemberian dosis 2mg. Kadar rata-rata kalsium plasma kelompok perlakuan dengan pemberian dosis $8 \mathrm{mg}$ adalah 8,78575 mg/dL, Kadar kalsium dalam darah pada kelompok tikus ini mengalami penurunan dibandingkan kelompok kontrol negatif dan berada ditahap hipokalsemia ringan. Namun kadar kalsium dalam kelompok pemberian dosis $8 \mathrm{mg}$ ini mengalami peningkatan kadar kalsium dibandingkan dengan kelompok pemberian dosis $2 \mathrm{mg}$ dan $4 \mathrm{mg}$. Sedangkan kadar rata-rata kalsium plasma kelompok perlakuan dengan pemberian dosis $16 \mathrm{mg}$ adalah $10,880 \mathrm{mg} / \mathrm{dL}$. Kadar kalsium dalam darah pada kelompok tikus ini jauh mengalami peningkatan kadar kalsium darah dibandingkan pemberian dosis $2 \mathrm{mg}$, $4 \mathrm{mg}$ dan $8 \mathrm{mg}$.

Dari tabel hasil keluaran uji analisa statistic menggunakan program statistic SPPS for Window, dapat disimpulkan bahwa dari uji ANOVA menunjukkan terdapat pengaruh langsung dosis pemberian ekstrak buah delima merah terhadap kadar kalsium darah tikus hal ini dapat dilihat dari nilai $\mathrm{F}$ sebesar 43,926 dengan signifikan pada $\mathrm{p}=$ 0.000 yaitu (Sig. $0,000<0,05$ ).

Tabel 6. Uji Anova pengaruh ekstrak buah delima merah terhadap kadar kalsium

\begin{tabular}{cccccc}
\hline & $\begin{array}{c}\text { Sum of } \\
\text { Squares }\end{array}$ & df & Mean Square & F & \multirow{2}{*}{ Sig. } \\
\hline Between Groups & 106.192 & 4 & 26.548 & & \\
Within Groups & 9.066 & 15 & 43.926 & .000 \\
Total & 115.257 & 19 & .604 & & \\
\hline
\end{tabular}

Dari hasil penelitian yang telah dilakukan dan telah diuraikan, bahwa pemberian ektrak buah delima merah sebanyak 2 (dua) kali sehari pada pada tikus dengan tingkat dosis berbeda, menghasilkan kadar kalsium darah yang berbeda. Kadar kalsium darah tikus putih (Rattus norvegicus) meningkat secara signifikan sejalan dengan peningkatan dosis ektrak buah delima merah yang diberikan. Dari data yang didapat, kadar kalsium darah tikus menurun sangat rendah pada dosis pemberian $2 \mathrm{mg}, 4 \mathrm{mg}$, 8mg. Kadar kalsium darah tikus pada ke-tiga kelompok perlakuan tersebut sudah pada taraf Hipokalsemia. Namun semakin tinggi dosis yang diberikan semakin meningkat pula 
kadar kalsium yang terdapat didalam darah tersebut. Sedangkan pada dosis pemberian $16 \mathrm{mg}$ mengalami peningkatan kadar kalsium dari kontrol.

Terjadinya hipokalsemia ini merupakan kejadian yang tidak diprediksi sebelumnya. Pada penelitian ini penyebab terjadinya hipokalsemia pada tikus putih dengan pemberian dosis ekstrak buah delima merah $2 \mathrm{mg}$, $4 \mathrm{mg}$ dan $8 \mathrm{mg}$ belum dapat diketahui, namun diduga hal ini disebabkan oleh pemberian ekstrak buah delima dengan dosis tersebut belum mengandung kadar kalsium yang cukup untuk dapat membantu meningkatkan kadar kalsium dalam darah. Menurut USDA National Nutrient dalam The National Agricultural Library pada tahun 2014 menyebutkan bahwa kadar kalsium yang terdapat pada buah delima (Punica granatum) ini sebesar $10 \mathrm{mg}$ dalam $100 \mathrm{~g}$ sedangkan kadar fosfor yang terkandung didalam buah delima sebesar $36 \mathrm{mg}$ dalam 100g. ${ }^{5}$ Asupan nutrisi dari pangan yang diberikan kepada tikus juga telah mengandung mineral kalsium dan fosfor. Jumlah fosfor yang lebih tinggi menyebabkan terganggunya keseimbangan rasio kalsium berbanding fosfor. Menurut Depkes RI tahun 2008 rasio Ca:P normal dalam tubuh adalah 2:1. Dalam kondisi rasio yang cukup ideal ini penyerapan terhadap kalsium menjadi optimal. Walaupun fosfor adalah zat gizi yang penting, perlu dipertimbangkan bahwa jumlah yang berlebihan dapat merugikan. ${ }^{14}$
Fosfor secara normal mempertahankan suatu keseimbangan dengan kadar kalsium yang serasi didalam tubuh. Kadar fosfor dalam darah cenderung berbanding terbalik dengan kadar kalsium dalam darah. Naiknya salah satu dari ke dua unsur tersebut akan diikuti oleh turunnya unsur yang satunya. Peningkatan konsumsi makanan yang mengandung fosfor akan meningkatkan konsentrasi fosfor serum, sementara kalsium yang terionisasi dalam serum akan mengakibatkan peningkatan sekresi hormon paratiroid yang menyerap kalsium dalamtulang. Tingginya konsumsi fosfat mengakibatkan terjadinya hiper paratiroidisme sekunder sehingga mengganggu homeostasis kalsium. ${ }^{15}$ Peneliti menduga bahwa pemberian dosis ekstrak buah delima $2 \mathrm{mg}$, $4 \mathrm{mg}$, dan $8 \mathrm{mg}$ belum mampu meningkatkan kadar kalsium dalam darah tikus putih (Rattus norvegicus) namun dengan semakin meningkatnya dosis ekstrak delima yang diberikan maka semakin meningkat pula kadar kalsium dalam darahnya.

Pada pemberian dosis 16mg ekstrak buah delima mengalami peningkatan kadar kalsium dalam darah dibandingkan kelompok kontrol, sehingga dapat disimpulkan pada dosis 16mg ekstrak buah delima mengandung kalsium yang cukup untuk membantu meningkatkan kadar kalsium dalam darah tikus putih namun dalam jumlah yang belum signifikan. Hal ini menunjukan pada dosis 16mg ekstrak inilah yang baru 
mampu mencapai titik seimbang dari ratio kalsium berbanding fosfor. Sehingga dapat disimpulkan dosis terkecil dari ekstrak buah delima dalam peningkatan kadar kalsium dalam darah sebesar 16mg.

\section{SIMPULAN}

Dari penjelasan diatas dapat disimpulkan bahwa kadar kalsium darah tikus putih (Rattus norvegicus) meningkat sejalan dengan peningkatan dosis ekstrak buah delima merah (Punica granatum) yang diberikan. Kadar kalsium darah tikus menurun sangat rendah pada dosis pemberian $2 \mathrm{mg}, 4 \mathrm{mg}, 8 \mathrm{mg}$ dibandingkan kontrol negatife. Namun semakin tinggi dosis yang diberikan semakin meningkat pula kadar kalsium yang terdapat didalam darah tersebut. Sedangkan pada dosis pemberian $16 \mathrm{mg}$ mengalami peningkatan kadar kalsium dalam darah dibandingkan dengan kelompok kontrol namun tidak signifikan. Sehingga dapat disimpulkan pada dosis 16mg ekstrak buah delima mengandung kalsium yang cukup untuk membantu meningkatkan kadar kalsium dalam darah tikus putih.

\section{DAFTAR PUSTAKA}

1. Loupy, A., Ramakrishnan, S.K., Wootla, B., Chambrey, R., Faille, Rdl, et al. 2012. PTH-Independent Regulation of Blood Calcium Concentration by the Calcium-Sensing Receptor. The Journal of Clinical Investigation.Volume 122 Number 9.

2. Cosman, F. 2009. Osteoporosis: Panduang Lengkap Agar Badan Anda
Tetap Sehat.Yogyakarta : B-Frist.

3. Jayanti, T., Cecilia, G.J.L., Agus, S. 2013. Toxicity Assay Of Extract Pomegranate (Punica granatum) On BHK21 Fibroblast Cells Culture (Expremental Laboratory Observasional). Surabaya. Fakultas Kedokteran Gigi Universitas Airlangga. Research Report.

4. Haas, E.M. 2006. Calcium. Staying Healthy with Nutrition, Celestial Arts.Artikel.Diakses27januari,2014.http://w ww/healthy.net.library/ books/haas/minerals/ca.htm.

5. USDA National Nutrient Database for Standartd Reference Release 27, 2014.Full Report (All Nutriens) 09286, Pomegranates, raw.The National Agricultural Library. Report date: Desember 15, 2014.

6. Marhari, O.Y., Dewi, K.K. 2014. Khasiat Ajaib Delima. Cetakan Pertama. Jakarta Timur. Penerbit Padi.

7. Sugianto, N.L. 2011. Pemberian Jus Delima Merah (Punica Granatum) Dapat Meningkatkan Kadar Glutation Peroksidase Darah Pada Mencit (Mus Musculus) Dengan Aktivitas Fisik Maksimal. Universitas Udayana. Tesis.

8. Suranto, A. 2011.Terbukti Pome Tumpas Penyakit. Cetakan Pertama. Jakarta. Penerbit Pustaka Bunda, Grup Puspa Swara.

9. Anwar, S.A. 2009. Pengaruh Kalsium dan Vitamin D3 Terhadap Stabilitas Tulang Alveolar - Studi pada Tikus Jantan Putih (Rattus Norvegicus).Jurnal Media Medika Indonesiana.Volume 43, Nomor 5.

10. Setyorini, A., Suandi, I.K.G., Sidiartha, I.L., Suryawan, W.B. 2009. Pencegahan Osteoporosis dengan Suplementasi $\mathrm{Ca}++$ dan Vit D pada Penggunaan Kortikosteroid Jangka Panjang.Jurnal Sari Pediatri.Volume 11, Nomor 1.

11. Khairunnisa, D. 2011. Uji Aktivitas Penyembuhan Luka Dari Ekstrak Calyx Rosela (Hibiscus Sabdariffa Linn) pada Mencit. Padang. Universitas Andalas. Skripsi.

12. Zobda, P.R., Pramana, W.M.A., Padaga, M.C. 2012. Pengaruh Tepung Tulang Ikan Tuna Madidihang (Thunnus albacares) Terhadap Kadar Kalsium dan Fosfor dalam Darah Tikus Putih (Rattus norvegicus) Model Ovariektomi. Program Studi Pendidikan Dokter Hewan Universitas Brawijaya.Jurnal.

13. DiaSys Diagnostic Systems. 2009. Calcium AS FS[Brosur]. Germany. 
Variety : Efektivitas ekstrak buah delima (Punica Granatum)...

Distributed by Diagnostika Sistem Indonesia.

14. Meikawati, W., Muis, F., Nugraheni, S., Achadi, S. 2009. Faktor yang Berhubungan dengan Kepadatan Tulang Remaja (Studi di SMA Negeri 3 Semarang). Jurnal Gizi Indonesia. Program Magister
Gizi Masyarakat Universitas Diponegoro. Jurnal.

15. Sabri, M. 2011. Aktivitas Ekstrak Etanol Batang Sipatah-patah (Cissus quadrangula salisb) sebagai Antiosteoporosis pada Tikus (Rattus norvegicus).Institut Pertanian Bogor. Jurnal. 